\title{
Research on the correlation between ocean energy policy and other policies*
}

\author{
Wan-Jun Wang ${ }^{\dagger}$, Jia-Cheng Hao, Yong-Qiang Zhu and Rui-Hua Xia \\ State Key Laboratory for Alternate Electrical Power System with \\ Renewable Energy Sources, North China Electric Power University, \\ Beijing, China \\ E-mail:470287047@qq.com \\ www.ncepu.edu.cn
}

\begin{abstract}
Ocean energy is a kind of clean and renewable energy source. In recent years, the development of ocean energy has become more and more important. With the development of ocean energy, our country has formulated some ocean energy policies. Similar to other areas of development, the ocean energy policy have a certain correlation with the other renewable energy policy, ecological environment, social economy and even national renewable energy development strategy. This paper analyzes the relationship between them from above several aspects, which can provide reference for the further development of ocean energy.

Keywords: Ocean Energy Policy; Renewable Energy; Ecological Environment; Social Economy; National Development Strategy.
\end{abstract}

\section{Introduction}

Ocean energy is an important renewable clean energy in the ocean, which includes tidal energy, wave energy, and ocean thermal power and so on. In recent years, in the context of global warming, the world's major ocean countries generally pay attention to the development and utilization of ocean energy. In order to reduce the dependence on oil coal and other energy sources, many countries have developed a corresponding development plan of ocean energy.

Our country ocean economy is speeding up adjustment and optimization during "the Twelfth Five-Year Plan", the construction of ocean energy policy system will have a great impact on the development of ocean renewable energy in the future, then it will has some influence on the other renewable energy policy, ecological environment, social economy and even national development strategy. This article will analyze the relationship between them from above several aspects.

\footnotetext{
${ }^{*}$ This work is supported by Ocean energy integrated support service platform construction.
} 


\section{The Relationship between Ocean Energy Policy and Other Renewable Energy Policies}

According to the literature [1] in twenty-first Century, China's renewable energy industry has reached a certain scale. New energy and renewable energy development and utilization have been close to the amount of energy provided by oil, natural gas, which becomes an important part of the energy system. The National Renewable Energy Law of the People's Republic of China has been introduced. Since 2007, hydropower, wind power, solar power and biomass in the field of 'the Twelfth Five-Year Plan' special development plan has also been formulated. Compared with them, the development of ocean energy is relatively backward. But ocean energy development is not only the national government departments, but also the local government and the development of the whole society. In terms of policy, although the characteristics and development of a variety of renewable energy is different, but the development of ocean industry can learn from the successful experience of other renewable energy policy, and reference to other renewable energy policy when establishing related policy, such as formulating strategic objectives and overall plan for the long-term development of ocean energy, perfecting the market mechanism and Implementing specific economic incentive policies, promoting industrial diversification and enhancing market awareness, promoting the improvement of technology research and development ability and so on. At the same time, to avoid the same mistakes, the problems exposed in other renewable energy policies should be paid attention to.

Due to the research and development of ocean energy, the development and utilization of ocean energy is weaker than other renewable energy sources. In view of the important status and development prospects of the ocean energy in the national economy, the state should give the ocean more favorable policies in the ocean than wind energy and solar energy, and Increase the development of the ocean energy. Due to the vigorous development of wind energy, solar energy and other renewable energy sources, the implementation of ocean energy industry will affect the status and implementation of other renewable energy sources in China's energy development. Our country need to coordinate the development of a variety of renewable energy and support efforts, and promote the common development of all kinds of renewable energy industry, realize the sustainable development of economy and society.

\section{Ocean Energy Policy and Ecological Environment}

Ocean renewable energy is the biggest and the cleanest energy on the planet with no fuel and no pollution. Although ocean renewable energy is the ideal 
clean energy to improve the environmental and climatic issues, there are some potential environmental problems in the ocean energy development process. For instance, tidal power plants would not only change the tidal range and the tide, but also change the water temperature and water quality, which would bring some impact on the surrounding ocean environment. At the same time, dam construction also could bring some impact on the estuary environmental problems, such as the impact on underground water and drainage as well as the enhancement of coastal erosion. While developing ocean energy, therefore, we need to fully occupy the consideration and comprehension of the impacts on ocean ecological environment [2]. According to the literature [3], it is summarized in Table 1 below:

Table 1. Classification of the environmental impact of the ocean.

\begin{tabular}{|c|c|}
\hline Classification & Contents \\
\hline Source of influence & $\begin{array}{l}\text { Ocean energy device, Dynamic environmental changes caused } \\
\text { by ocean energy device, Ocean energy conversion effect, } \\
\text { Chemistry }\end{array}$ \\
\hline Environmental receptor & $\begin{array}{l}\text { Physical environment, Biological species, Fish and fishery } \\
\text { resources, Sea birds, Ocean mammals, Food chains }\end{array}$ \\
\hline Effectiveness & $\begin{array}{l}\text { Single / short term effects, composite / short term effects, single } \\
\text { / short term effects, composite / long-term effects }\end{array}$ \\
\hline $\begin{array}{l}\text { Environments change } \\
\text { mode }\end{array}$ & $\begin{array}{l}\text { Quantity change, community change, biological process change, } \\
\text { physical structure change }\end{array}$ \\
\hline Impact consequences & $\begin{array}{l}\text { Water flow reduction, water quality environment change, } \\
\text { Landscape changes in coastal zones, fish survival are threatened }\end{array}$ \\
\hline
\end{tabular}

The ecological protection of the environment is one of the original intentions of ocean energy development. Therefore, the development of ocean energy industry should not be based on the expense of the ocean environment. So our country should formulate relevant laws and regulations and improve the necessary system of technology development. At the same time, we should attach great importance to ocean spatial planning, strengthen environmental assessment, and ensure the eco-friendly ocean renewable energy industry.

For ocean energy development, the establishment of appropriate environmental impact assessment system is equally important. All applications for development projects must consider the coordination with neighboring stakeholders, while the applicant must describe the existing environment, engineering details, and the potential impact of the project, public safety, safeguards of environmental resources, guaranteed removal and reconstruction funds, and counseling records when necessary. In addition, the ocean energy development should be recommended in harmony with the ocean engineering construction, which plays a multiplier effect. 
While developing the ocean energy, environmental protection system and measures should be strictly adhered to, as the relevant measures and procedures should be refined and supplemented by relevant departments with a consensus in order to ensure sustainable development of ocean energy industry. While establishing the ocean energy development strategies and policies, it should be fully considered that its environmental benefits, the protection of the ocean environment, and the assurance for the sustainable use of ocean resources. In short, while focusing on improving ocean energy policy system, we need to consider strengthening the impact of the ocean environment policy. There is a close relationship among the improvement of ocean environmental protection law, the enhancement of the ocean environmental protection awareness, and the promotion of the ocean energy policy system construction.

\section{Ocean Energy Policy and Social Economy}

The development and utilization of new energy has become the trend of the times under the influence of the external environment. From the perspective of economic development, ocean energy development can drive the development of relevant industries and play the energy advantage of the coastal areas, which is not only ease the large demand for energy in coastal areas, but also promote the economic development of the coastal areas. Ocean energy development will form the industrialization which is a new growth point in the future development of ocean economy and promote the optimization and upgrading of ocean industrial structure. From the perspective of social development, Ocean energy development is the need of the sustainable development of our society and the requirement of environmental protection. Our country relies on the ocean energy development to adjust the energy structure and solve the energy crisis. Ocean energy development has impact on the construction of China's sustainable development, creating more employment opportunities, improving the quality of residents' life, developing other social benefits [4].

Economic growth and industrial structure optimization are the direct factors that affect the economy. Economic growth is affected by the number of listing corporation in the ocean industry, ocean products exports, ocean energy industry product productivity and other factors. The optimization of industrial structure is affected by the factors such as the labor capital output rate of the ocean industry, the total imports of ocean energy industry. Quality of the residents' life, energy structure improvement and technical progress constitute the direct factors of promoting social progress. The above three direct factors are also affected by the ocean energy industry per capita consumption level and other factors.

China's coastal provinces' GDP accounted for about 70\% of the country. According to the country's development plan and long-term goal, China's coastal 
areas will be the first to achieve a comprehensive well-off society, but energy has become a major issue which restricts the development of coastal areas. So developing large-scale ocean energy is a feasible strategy to solve this problem. Playing the advantage of ocean energy can ease the large demand for energy in coastal areas and promote the development of related industries in coastal areas and promote the economic development in coastal areas.

The evaluation of social and economic impact is also very important before the sea can be developed and utilized. For rational exploitation and utilization of ocean energy, we should evaluate the effectiveness of ocean energy development and development program; comprehensively consider economic and social benefits of the ocean energy industry formulating scientific ocean energy development strategy and related policies. In recent years, China's government has issued relevant policies and regulations to regulate the development and utilization of ocean energy. The national "12th Five-Year" determined the ocean to be the national strategy for the development of energy, various ocean economic strategic areas have also made important arrangements for the development of the ocean and established the objectives and tasks for the development of the ocean. Shandong Peninsula blue economic zone also setted up provincial departments of ocean energy planning. The research and formulation of these policies provide a valuable reference for the evaluation of the social and economic impact of the ocean energy development in our country.

\section{Ocean Energy Policy and National Development Strategy}

The current international situation is that all the developed nations compete to formulate and implement development strategy of new energy. But in China, compared to traditional energy, the development of new energy is relatively lagging and weakness. In order to meet a double security of energy supply and use and the needs of industrial characteristics of cultivate new economic growth areas, it is necessary for China to establish and implement development strategy of new energy. On the one hand, we need to keep abreast with the current development of new energy, gradually become a leader of new energy industry and lead the world ecotype energy construction and development direction. On the other hand, we continue to develop new energy technologies and make it meets the growing needs of energy and power. We hope new energy can become one of the alternative energy source, mainstream source and dominant energy source in the future, and finally improve people's material conditions and living quality[5].

Facing the new change of international economic structure and new development of technological revolution, countries of vast maritime territory, such as the United States, France, Canada, have already made policy and plans 
for ocean renewable energy technology and industry. These measures make ocean renewable energy industry and its related emerging industry in these countries develop rapidly and make economies of scale basically formed. In new period, taking a strategic view to develop new energy industry means new energy industry has being attached great importance at the national level. The development of new energy in China is facing unprecedented new opportunities and government has presented the concept of strategic marine emerging industry.

As one of the strategic emerging industry in ocean area, strategic ocean emerging industry is put forward with the presenting of the strategic emerging industry. In 2010, the cultivation and development of strategic ocean emerging industry are put on the agenda. In 2012, 'Fujian Province Planning for Development of Ocean Economy' was approved, and Fujian province became the fifth ocean economy strategic area at the state level. In April 2012, ocean energy was determined to be national strategic development energy in the 12th Five-Year Plan [6].Developing strategic ocean emerging industry needs to promote ocean economic development. And the promotion of ocean economic development should serve national development strategy. According to strategic decision-making of 'accelerating the transformation of economic development mode' in the 12th Five-Year Plan, we will develop strategic ocean emerging industry with the purpose of promoting the restructuring of industry and transforming economic development mode. We should make a rational exploitation and comprehensive use of ocean resources, develop strategic ocean emerging industry. Promoting spanned development of ocean economy can promote our ocean undertaking, serve the achievement of the 12th Five-Year Plan, and provide a reference for the strategy formulation of ocean energy exploitation in the next Five-Year Plan.

The development strategy direction of new energy industry in China are guaranteeing energy supply, preserving the ecological environment, increasing energy efficiency, improving energy structure, and advancing scientific development. Its goal-level are effective supplement energy, alternative energy source, mainstream source and dominant energy source. Its connotation shows in being highly valued, priority development, long term support, depending on innovation and being determined by the markets. Ocean energy policy is bound up with national new energy development strategy. Aiming at competing for the economy and technology commanding point and achieving economic advancement and national rejuvenation, cultivating strategic ocean emerging industry is promoted as an important strategic decision. Strategic ocean emerging industry represents the direction of ocean science and technology innovation and development strategy of the ocean renewable energy field in 
China. It is necessary to promote optimization of the ocean economy structure and the transformation of ocean economic development mode fundamentally and have strengths in ocean science and technology and capability of independent innovation.

\section{Summary}

As shown above, there are some contact between ocean energy policy and other renewable energy policy, ecological environment, social economy and national renewable energy development strategy. Overall, ocean energy development is still in the early stage. With the development of ocean energy development technology, perfecting national policies, coordinating the development of renewable energy sources, focusing on the protection of the ecological environment, promoting social and economic progress, assisting the formulation of the national renewable energy development strategy, these are of great significance to the development of ocean energy. It hopes that this paper can provide reference for the future development of ocean energy development and utilization activities and environment, economy and society.

\section{References}

1. Gong Chun Bo, The development Policy Research on The New Ocean Strategic Industries in China [D]. Shandong University, 2009.(In Chinese)

2. Yu Hao, Xu Huan Zhi, Zhang Zhen, et al. Research progress on environmental impacts of the utilization and explosion of ocean renewable energy[J]. Ocean Development and Management 2014(4): 69-74. (In Chinese)

3. BOEHLERT G W, GRULL A B. Environmental and ecological effects of ocean renewable energy development: A current synthesis [J]. Oceanography, 2010, 23(2): 68-81

4. Yin Ke Dong, Huang Hang Zhou. Evaluation research on socio-Economic impact of ocean energy exploitation[J].Journal of Ocean University of China (social science edition),2014,01:38-44.(In Chinese)

5. Zhang Xian Chang. Research on the development policy of China's new energy industry [D]. Party School of the CPC Central Committee, 2014.(In Chinese)

6. Zhong Wen Wen. Policy Research on the development of China's strategic ocean emerging industries [D]. Ocean University of China, 2011.(In Chinese) 